\title{
AZ IFRS 9 BEVEZETÉSÉNEK TAPASZTALATAI A BANKSZEKTORBAN
}

Gulyás Éva - Somogyi Cintia ${ }^{1}$

2018-tól a hitelintézetek legtöbbje az IFRS-ek szerint köteles elkészíteni beszámolóját. Az áttérés elvárt hatása az összehasonlíthatóság növelése, valamint az adminisztrációs terhek csökkentése. Tanulmányunkban megvizsgáltuk, hogy a válaszadók tapasztalatai alátámasztják-e az elvárások megvalósulását. A korábbi felmérések és saját tapasztalataink alapján 2018 nyarán kérdőív segítségével mértük fel a bankoknak az IFRS 9 bevezetésével kapcsolatos tapasztalatait.

Kutatásunk árnyalja a korábbi eredményeket, amelyek szerint az áttérés sikerességét a magyar nyelvü szakirodalom rendelkezésre állása, az észszerü határidők biztosítása, valamint a megfelelő GAP-analízis biztosítja, míg nehézséget az ismeretek hiánya és az egyszeri magas átállási költségek jelentik.

Jelentős különbséget tapasztaltunk attól függően, hogy az adott bank az IFRS 9-re való áttérés előtt készített-e már IFRS-ek szerinti egyedi beszámolót. A legnagyobb kihívást az IT-rendszer kiforratlansága jelentette, míg a legfontosabb számviteli kihívások közé az értékvesztés, az SPPI-tesztek és az adózási kérdések kerültek.

A megkérdezett hitelintézetek szakértőinek véleménye a válaszok alapján nem igazolta az IFRS-ek és az IFRS 9 bevezetésével elvárt előnyöket, a hátrányokat hangsúlyosabbnak tekintették.

JEL-kódok: G21, G23, G28, M41

Kulcsszavak: számvitel, bankrendszer, szabályozás, pénzügyi instrumentumok

\section{BEVEZETÉS}

A 2018-as év a hazánkban működő hitelintézetek legtöbbje számára kiemelkedő jelentőségű volt, hiszen ettől az évtől kezdve - kevés kivételtől eltekintve - valamennyi hitelintézet az IFRS-ek szerint köteles elkészíteni számviteli beszámolóját (Mészáros, 2015). Az új elöírás a hitelintézetek azon részének, amelyeknek vala-

1 Gulyás Éva a Budapesti Corvinus Egyetem Vezetői Számvitel tanszékének adjunktusa. Somogyi Cintia az FX Software Zrt. szakértője. 
mely értékpapírját az Európai Unió tőzsdéin jegyzik vagy jegyezték korábban, nem jelentett teljes újdonságot, hiszen ezen vállalatok már 2005-től kötelesek voltak konszolidált beszámolójukat az IFRS-ek szerint elkészíteni (Vajay, 2015). Ezen vállalatok számára is újdonság volt azonban az IFRS-eknek az egyedi beszámoló szintjén történő alkalmazása, annak ellenére, hogy az ilyen konszolidált beszámoló az egyedi vállalati adatok IFRS-ek szerinti meghatározása nélkül nyilvánvalóan nem volt elkészíthető. A hitelintézeti szektor más része korábban ugyan nem készített sem egyedi, sem konszolidált szinten IFRS-ek szerinti beszámolót, ám anyavállalata számára ilyen tartalmú adatok szolgáltatására kötelezett lehetett, így valamilyen szintű IFRS-ismeretekkel rendelkezett már. A szektor bizonyos szereplői számára azonban mind az IFRS-ek szerinti adatok előállítása, mind pedig az új struktúrájú és tartalmú pénzügyi kimutatás összeállítása teljesen új feladatot jelentett. Az IFRS-ekre való áttérés elvárt hatása a versenyképesség és az összehasonlíthatóság növelése, valamint az adminisztrációs terhek csökkentése volt. Tanulmányunkban arra kerestük a választ, hogy ezen elönyöket a vizsgált intézmények mennyire érzékelik, illetve milyen más előnyöket, netán hátrányokat jelent számukra ez az áttérés. A lehetséges válaszok felmérése érdekében több korábbi tanulmányt tekintettünk át, amelyeket a következő fejezetben mutatunk be, valamint ezek eredményei alapján a 2018 július-szeptemberi időszakban kérdőív segítségével mértük fel a bankoknak az IFRS 9 standard bevezetésével kapcsolatos tapasztalatait.

A korábbi - nem hitelintézeti és nem IFRS 9 fókuszú - kutatások eredményei szerint az áttérés sikerességét a magyar nyelvü szakirodalom rendelkezésre állása, az észszerü (1-2 éves) határidők biztosítása, valamint a megfelelő GAP-analízis biztosítja, míg nehézséget az ismeretek hiánya és az egyszeri magas átállási költségek jelentenek (Bartha et al., 2014). Az IFRS 9-re fókuszáló - még az áttérés előtt készült - Deloitte-kutatás azt mutatta, hogy a felmérésben szereplők számára várhatóan a pénzügyi instrumentumok besorolása, az értékvesztésképzés módszertanának módosulása, a késedelmes tételek meghatározásának módja, valamint a közzétételi követelmények változása okoz majd gondot (Veszprémi et al., 2018).

Saját kérdőívünk megszerkesztése és a kapott eredmények feldolgozása előtt azzal a feltételezéssel éltünk, hogy az IFRS 9-re való áttéréssel kapcsolatos, jelenlegi tapasztalatok hasonlítanak majd az IFRS-ekre való áttérésre vonatkozó, korábbi felmérések eredményeire. Ugyanakkor arra számítottunk, hogy a válaszok jelentősen különböznek majd aszerint, hogy a válaszadó kis vagy nagy banknak minősül-e, már 2017-ben áttért-e az egyedi beszámoló szintjén az IFRS-ek alkalmazására, illetve, hogy szüksége volt-e korábban bármilyen okból IFRS-ek szerinti adatokra. Azt feltételeztük, hogy a nagyobb bankok már 2017-ben áttértek az egyedi IFRS-beszámolóra, vagy legalábbis korábban is előállítottak az IFRS- 
eknek megfelelő adatokat, így ők az előnyöket jelentősebbnek, a hátrányokat pedig kevésbé jelentősnek ítélik majd.

Cikkünkben a kapott válaszokat elemeztük, szem előtt tartva a korábbi kutatások eredményét, igazolni, illetve cáfolni próbálva saját feltételezéseinket.

\section{A KORÁBBI KUTATÁSI EREDMÉNYEK BEMUTATÁSA}

A primer kutatás megvalósítása előtt szekunder kutatást végeztünk az IFRS-ekre történő áttéréssel kapcsolatos, korábbi felmérések megismerése céljából. Összesen négy - egy közép- és kelet-európai országok körében végzett, illetve három hazai vállalkozások körében végzett - kérdöíves felmérés eredményeit foglaljuk össze.

A Big $4^{2}$ könyvvizsgálócégek közös kérdőívet állítottak össze az IFRS alkalmazásával és bevezetésével kapcsolatos tapasztalatok megismerése céljából. A kérdőívet 2013 nyarán 20 olyan, elsősorban európai országba küldték ki, ahol az IFRS-ek alkalmazása kötelező a tőzsdén jegyzett vállalatok konszolidált pénzügyi kimutatásaira, illetve nagyobbrészt az egyedi beszámolókra vonatkozóan is. A kérdőív az IFRS-ek bevezetéséhez kapcsolódó sikertényezők, előnyök és hátrányok, valamint az adózással való kapcsolat felmérésére terjedt ki (Bartha et al., 2014).

Az Ernst and Young (továbbiakban: EY) 2015 tavaszán készített kérdőíves felmérést hazai vállalkozások bevonásával annak érdekében, hogy feltérképezze az IFRS-ekre történő hazai áttéréssel kapcsolatos tapasztalatokat. A kérdőívet 49 vállalkozás töltötte ki, ezek 25 százaléka a pénzügyi szektorban végzi tevékenységét. A kitöltők 78 százalékának anyavállalati jelentéscsomag vagy IFRS pénzügyi kimutatás formájában már a felmérés előtt is volt IFRS szerinti beszámolási kötelezettsége. A felmérés az IFRS-ek hazai bevezetésének sikertényezőit, kihívásait, illetve előnyeit foglalja össze (Bartha et al., 2015).

A PricewaterhouseCoopers (továbbiakban: PwC) 2016 októberében közel 100 vállalkozás bevonásával felmérést készített az IFRS-ekre történő áttéréssel kapcsolatban, amelynek célja a vállalkozások véleményének megismerése, illetve az átlagos felkészültségi szint felmérése volt (Kökény, 2017).

A Deloitte 2018-ban másodjára készített kérdőíves felmérést arra vonatkozóan, hogy miképp gondolkodnak a vállalatok az IFRS-ekre történő áttérésről, valamint annak kihívásairól. Ebben a felmérésben már közvetlenül az IFRS 9 standarddal kapcsolatos kérdések is szerepelnek, amelynek eredményeire külön kitérünk (Veszprémi et al., 2018).

2 Deloitte Kft., Ernst \& Young Könyvvizsgáló Kft. (EY), KPMG Hungária Kft., PricewaterhouseCoopers Könyvvizsgáló Kft (PwC). 


\subsection{Az IFRS-ek bevezetésének sikertényezői és kihívásai}

Az IFRS-ek sikeres bevezetésének egyik kulcstényezője megfelelő számú IFRSismeretekkel rendelkező számviteli szakember képzése, ami Magyarországra nézve is kiemelt fontosságú, hiszen a hazai számviteli szabályozás és az IFRSek között jelentős eltérések vannak (Bartha et al., 2014). A Deloitte-felmérésben szereplő válaszadók 54 százaléka gondolta úgy, hogy nem rendelkezik az átálláshoz szükséges szaktudással (Veszprémi et al., 2018), míg a PwC-felmérés alapján a válaszadók 25 százaléka tekintette nehézségnek az IFRS-szakemberek hiányát (Kökény, 2017). Ezek alapján látható, hogy elengedhetetlen fontosságú a folyamatos képzések biztosítása, valamint ezzel együtt a naprakész képzési anyagok kialakítása (Bartha et al., 2014). Emellett kiemelt fontosságú, hogy elegendő és megfelelő minőségű magyar nyelvü szakirodalom álljon a számviteli szakemberek rendelkezésére, amely az EY-felmérésben szereplő vállalatok 84 százaléka szerint a sikeres áttérés egyik alapvető feltétele (Bartha et al., 2015).

Az IFRS-ekre történő sikeres áttérés másik kulcsfontosságú tényezője, hogy a számviteli szakértők nyitottak legyenek a változásokra. Ebben nyújt segítséget a szabályozó hatóságok megfelelő kommunikációja, amely lehetővé teszi a vállalkozások számára, hogy időben fel tudjanak készülni az esetleges változásokra, és eleget tudjanak tenni az felmerülő kihívásoknak. A megfelelő kommunikációval megelőzhető, hogy bizonytalanság alakuljon ki az áttéréssel kapcsolatban, és a számviteli szakértők részéről ellenállás mutatkozzon a változásokkal szemben (Bartha et al.,2014).

A sikertényezők között kiemelendő az észszerü, betartható határidők elöírása a szabályozók részéről, amely ideális esetben egy éven túli, de két évnél rövidebb átmeneti időszakot jelent (Bartha et al., 2014). A kitűzött határidők betartását segíti, ha a vállalatok az áttérés kezdetén úgynevezett GAP-elemzést készítenek, amelynek a célja a hazai számviteli szabályok és az IFRS-ek közötti különbségek feltárása, beleértve az áttérésnek a müködési folyamatokra és kontrollokra, IT-területekre, valamint adózási kérdésekre gyakorolt hatásának vizsgálatát is (Bodor et al., 2017). A PwC felmérése alapján az áttérés megvalósításának hatékonysága nagymértékben összefügg a hatáselemzés elkészítésére fordított idővel. Azok a vállalkozások, amelyek átlagosan két-három hónapot foglalkoztak az áttérés hatásainak elemzésével, könnyebben vették a felmerülő akadályokat, és tartani tudták a kitüzött határidőket (Kökény, 2017).

A GAP-elemzés eredménye nagymértékben függ attól, hogy az adott vállalkozás készitett-e korábban IFRS-beszámolót vagy anyavállalati jelentéscsomagot. Az EYfelmérés alapján azoknak a válaszadóknak a 68 százaléka, akiknek már korábban is volt IFRS-tapasztalata, úgy gondolta, hogy a jelenlegi rendszereik és folyamataik képesek lesznek az IFRS-beszámolóhoz szükséges adatok előállítására; míg 
azok a vállalatok, amelyek nem rendelkeztek ilyen tapasztalattal, nagyobbrészt meg sem tudták ítélni, hogy milyen változásokra számíthatnak (Bartha et al., 2015).

A Big4-felmérésben szereplő országok a vártnál kisebb jelentőségű tényezőnek ítélték meg az adózási szabályoknak az IFRS-ekkel történő összehangolását, Magyarországon azonban az adózási kérdések is kiemelten fontosak, hiszen sok olyan adónem van, különösképpen a társasági adó és a helyi iparűzési adó, amelyekre jelentős hatással lesz az áttérés (Bartha et al., 2014).

\subsection{Az IFRS-ek bevezetésének előnyei és hátrányai}

A Big4-felmérésben szereplő országok az IFRS-ekre történő áttérés legnagyobb előnyének egyhangúan a pénzügyi kimutatások összehasonlithatóságát és átláthatóságát tekintették. A külföldi befektetők számára napjainkban alapvető elvárás a különböző országokban működő vállalkozások teljesítményének összemérése, amely a világszerte leginkább elfogadott számviteli szabályrendszer, az IFRS-ek bevezetésével valósítható meg. Ennek következtében azok az országok, amelyek már bevezették az IFRS-ek alkalmazását, versenyképesebbeknek, illetve a befektetők számára vonzóbbnak bizonyultak, mint azok az országok, ahol még nem történt meg az IFRS-ek befogadása (Bartha et al., 2014).

A válaszadók további előnyként emelték ki, hogy az IFRS-ek bevezetésének következtében javult a számviteli szakértelem. Ez egyrészt annak köszönhető, hogy a standardalkotók törekedtek arra, hogy közelebb hozzák a számvitelt az üzleti célokhoz, másrészt az IFRS-ek bevezetéséhez elengedhetetlen a számviteli tudás folyamatos karbantartása (Bartha et al., 2014).

Végül azon vállalkozások számára, akik az egyedi beszámolójukat a helyi jogszabályokkal, míg a konszolidált beszámolójukat vagy az anyavállalati jelentéscsomagjukat az IFRS-ekkel összhangban készítették el, az áttérés a párhuzamos könyvek vezetésének megszűnését, ezáltal az adminisztrációs terhek csökkentését eredményezte (Bartha et al., 2014).

Az IFRS-ek bevezetésének előnyei mellett számos nehézséget is kiemeltek a válaszadók, amelyek közül a legjelentősebbnek az ismeretek hiánya bizonyult. A Big4-felmérésben szereplő 20 országból 16 ország kiemelte, hogy számviteli szakértők nem rendelkeztek elegendő ismeretekkel és tapasztalattal ahhoz, hogy kezelni tudják az összetett vagy speciális ügyleteket, ami a standardok félreértelmezéséhez, valamint nem megbízható pénzügyi kimutatások összeállításához vezethet (Bartha et al., 2014).

További hátrány az IFRS-ek bevezetésének egyszeri magas költsége, amely alapvetően magába foglalja a GAP-elemzés elkészítéséhez, a rendszerszintü IT-fejleszté- 
sekhez, a munkavállalók képzéséhez, valamint a külső tanácsadók igénybevételéhez szükséges finanszírozást (Bartha et al., 2014).

\subsection{Az IFRS 9 bevezetése}

A Deloitte 2018-ban végzett felmérésében külön kitért az IFRS 9 standard kihívásainak feltérképezésére. A kutatásban résztvevők 91 százaléka rendelkezett valamilyen pénzügyi instrumentummal, azonban csupán 6 százalékuk pénzügyi szektorban tevékenykedő vállalkozás. Ennek következtében a felmérés eredményeit nem lehet a hitelintézeti szektorra vonatkoztatni, de mindenképpen érdekes megvizsgálni, hogy a gyakorlatban az IFRS 9 standard mely témakörei jelentenek kihívást a vállalkozások számára.

A felmérés alapján a következő területeken merültek fel nehézségek az IFRS 9 standard bevezetése során:

- pénzügyi eszközök besorolása (üzleti modell, SPPI-teszt);

- értékvesztési módszertan meghatározása;

- késedelmes tételek kezelése;

- közzétételi kötelezettségek.

A felmerült nehézségek miatt a válaszadók 82 százaléka fordult külső segítséghez, amely elsősorban anyavállalati tájékoztatást jelentett. Ezen kívül a megkérdezettek oktatásokon való részvétellel, valamint külső tanácsadók bevonásával sajátították el az IFRS 9 elöírásait (Veszprémi et al., 2018). Érdekes módon a PwC 2017es felmérésében mindössze a válaszadók egyharmada gondolta úgy, hogy külső szakmai segítségre van szüksége (Kökény, 2017).

\section{MÓDSZERTAN - A KÉRDÖÍV ÉS FELDOLGOZÁSA}

A korábbi felmérések csupán közvetetten nyújtottak információt a hitelintézeti szektorról, ezért annak érdekében, hogy felmérjük a hitelintézeteknek az IFRS 9 standard bevezetésével kapcsolatos tapasztalatait, kérdőíves felmérést készítettünk 15 hazai hitelintézet szakértőinek bevonásával.

A következőkben - a felmérés eredményeinek összefoglalása előtt - a kutatás módszertanát ismertetjük.

A primer kutatást kérdőív formájában végeztük, amelynek középpontjában az IFRS 9 áttérési projektben résztvevők (többek között: számviteli, IT, projektmenedzsment, kockázatkezelési területek) tapasztalatainak felmérése állt. A felmérés során arra kerestük a választ, hogy a megkérdezettek hogyan ítélik meg az 
áttérés sikerességét, milyen kihívásokkal találták szemben magukat a projekt során, illetve az IFRS 9 bevezetésének milyen előnyeit és hátrányait tapasztalták meg.

A kérdőívben nyitott, illetve zárt kérdéseket egyaránt alkalmaztunk. A zárt kérdéseknél minden olyan esetben „Egyéb” válaszadási lehetőséget biztosítottunk, amikor az általunk felsorolt lehetőségek nem voltak teljes körüek. A számszerü adatokra, illetve tényekre irányuló kérdések mellett értékelő kérdésekkel mértük fel a válaszadók IFRS 9 standarddal kapcsolatos véleményét. Ezen kívül néhány ellenőrző kérdés beépítésével lehetőség nyílt a válaszok következetességének megvizsgálására (Majoros, 2011). Az eredmény torzításának elkerülése érdekében, ha egy hitelintézettől több kitöltés is érkezett, és a nyilvánosan közzétett adatokból nem derült ki egyértelműen a helyes válasz, akkor bankokra vetítve, a válaszok módusza alapján elemeztük a kapott válaszokat.

A felmérés kiterjedt az áttérési projektben résztvevő területekre, mint például treasury, számvitel, IT, projektmenedzsment, kockázatkezelés. A kérdőív online elérhetőségét (Google Forms) és a letölthető változatát (Microsoft Word) e-mailben juttattuk el a válaszadóknak a 2018 júliusától szeptemberéig terjedő időszakban. Személyes kapcsolat esetén közvetlenül a megkérdezetteknek, annak hiányában e-mailen keresztül a könyvviteli feladatok irányításáért és vezetéséért felelős személynek továbbítottuk a kérdőívet.

A válaszadók kiválasztása nem valószínűségi mintavételi eljárással, azon belül önkényes mintavétellel történt (Majoros, 2011). Ennek következtében a minta nem tekinthető reprezentatívnak, így a felmérés eredményei csak a mintára volnának értelmezhetőek. Az eredmények kiterjeszthetősége érdekében - a kis mintaelemszám miatt - elvégeztük a következőkben ismertetett próbákat is.

Az elemzés kiindulópontjaként a kapott válaszok alapján egy egységes adatbázist építettünk Microsoft Excelben, majd elkülönítettük a magyarázó, illetve az eredményváltozókat, és különböző szempontok mentén kereszttábla-elemzéssel vizsgáltuk meg a válaszokat.

Az elemzést a leíró statisztikában is alkalmazható Cramer-féle asszociációs együthatóval, illetve az éta-négyzet mutatóval végeztük el. A Cramer-féle aszszociációs együttható két változó közötti kapcsolat szorosságát mutatja meg. Az együttható o és 1 közötti értéket vehet fel: a o-hoz közeli érték független, míg az 1-hez közeli érték nagyon erős kapcsolatra utal (SPSSABC, 2018c). Az éta-négyzet mutatóval pedig a csoportátlagok közötti eltérések mértéke vizsgálható, amelynek értéke megmutatja, hogy a magyarázó változó hány százalékban befolyásolta a csoportátlagok különbségét (Huzsvai-Vincze, 2012).

A változók közötti kapcsolatok ellenőrzésére a Fisher-féle egzakt próbát alkalmaztuk a Statistical Package for the Social Sciences (továbbiakban: SPSS) rend- 
szer segítségével. A Fisher-teszt kis elemszámú minta mellett is megmutatja, hogy $2 \times 2$-es kontingenciatáblán van-e szignifikáns kapcsolat két változó között (SPSSABC, 2018b). A teszt $\mathrm{R} \times \mathrm{C}$ - azaz nagyobb méretü - táblára történő kiterjesztésére a Fisher-Freeman-Halton-tesztet használtuk (IBM, 2016). Ezen kívül a skálás értékelő kérdéseket egymintás T-próba alkalmazásával elemeztük, amelylyel kis elemszámú minta esetén az átlagok közötti különbözőségeket lehet megvizsgálni (SPSSABC, 2018a).

A válaszadók nem a hitelintézetek hivatalos álláspontját képviselték, hanem saját meglátásuk szerint töltötték ki a kérdőíveket.

\section{EREDMÉNYEK}

30 részvénytársasági formában működő hitelintézetnek, azon belül megközelítően 100 szakértőnek küldtük ki a kérdőívet. Összesen 15 hitelintézettől, illetve 28 szakértőtől érkezett válasz, ami 28 százalékos válaszadási arányt jelent. Ezek közül 1 kitöltés nem volt értékelhető, ezért a válaszadót kiszűrtük az elemzés során, tehát a továbbiakban 27 kitöltő válaszait vettük figyelembe.

\subsection{A magyarázó változók kiválasztása}

A kérdőív összesen 26 kérdést tartalmazott, illetve a válaszadók alapadatainak felvételére további két kérdés vonatkozott: a válaszadó melyik hitelintézetnél, illetve milyen területen (például: számvitel, IT, projektvezetés, kockázatkezelés) dolgozik. Ezek a kérdések kötelezően kitöltendő mezőként szerepeltek a kérdőívben, mert azzal a feltételezéssel éltünk, hogy magyarázó változónak fognak bizonyulni a további kérdések elemzése során.

A kitöltők 56 százaléka, azaz 15 fő számviteli szakértő volt, ezen belül 12 kitöltés treasury-számviteli területről, míg további 3 kitöltés hitelintézetek fökönyvelőitől érkezett. Ezen kívül IT-, kockázatkezelési, projektvezetési, kötelező jelentések, kontrolling, ALM-, mid-office-, valamint ügyvezetőségi területről érkezett válasz.

\subsubsection{Hitelintézetek csoportosítása}

A válaszadók munkahelyének azonosításával lehetőségünk nyílt arra, hogy a hitelintézetek egyedi és konszolidált beszámolójában szereplő adatok alapján további információhoz jussunk a bankokról. Azt feltételeztük, hogy bizonyos objektív ismérvek - például a hitelintézetek mérete, vagy a 2017-es évben az egyedi beszámolás szintjén alkalmazott számviteli szabályrendszer - jelentős hatással vannak arra, hogy a válaszadók miképp vélekednek az IFRS 9 standardra történő 
áttérésről, ezért a mintában szereplő hitelintézeteket három ismérv mentén vizsgáltuk:

- hitelintézetek mérete;

- 2017-ben egyedi beszámolás szintjén alkalmazott számviteli szabályrendszer;

- IFRS 9 áttérés előtti IFRS-beszámolási kötelezettség.

\section{Hitelintézetek mérete}

Először méret szerint a „Nagy bank”, illetve „Kis bank” csoportot hoztuk létre. A csoportosítást a 2017. 12. 31-ével befejeződő üzleti évre vonatkozó, egyedi éves beszámolókban szereplő mérlegfőösszegek robusztus átlaga (950,14 milliárd forint) szerint végeztük el. Az átlagnál magasabb mérlegföösszeggel rendelkező hitelintézeteket a „Nagy bank”, míg az átlagnál alacsonyabb mérlegföösszeggel rendelkező bankokat a „Kis bank” csoportba soroltuk. Ennek az alapján a mintában 7 nagy, illetve 8 kis bank szerepel.

A mérlegföösszeg az MNB által kiadott 2017-es Aranykönyvben mind a 40 részvénytársasági formában működő hitelintézetre ismert adat, ezért a méret szerinti csoportosítás mentén megvizsgáltuk, hogy a minta mekkora részét fedi le a teljes sokaságnak.

\section{1. táblázat}

A sokaság lefedettsége méret szerint

\begin{tabular}{lcccccc}
\hline & \multicolumn{2}{c}{ Nagy bankok } & \multicolumn{2}{c}{ Kis bankok } & \multicolumn{2}{c}{ Összesen } \\
\hline & $\begin{array}{c}\text { Bankok } \\
\text { száma }\end{array}$ & $\begin{array}{c}\text { Mérleg- } \\
\text { föösszeg } \\
\text { (Mrd Ft) }\end{array}$ & $\begin{array}{c}\text { Bankok } \\
\text { száma }\end{array}$ & $\begin{array}{c}\text { Mérleg- } \\
\text { föösszeg } \\
\text { (Mrd Ft) }\end{array}$ & $\begin{array}{c}\text { Bankok } \\
\text { száma }\end{array}$ & $\begin{array}{c}\text { Mérleg- } \\
\text { föösszeg } \\
\text { (Mrd Ft) }\end{array}$ \\
Minta & 7 & 18630 & 8 & 1531 & 15 & 20161 \\
Aranykönyv & 10 & 25036 & 30 & 6373 & 40 & 31409 \\
$\begin{array}{l}\text { Minta/ } \\
\text { Aranykönyv }\end{array}$ & $70 \%$ & $74 \%$ & $27 \%$ & $24 \%$ & $38 \%$ & $64 \%$ \\
\hline
\end{tabular}

Forrás: Saját szerkesztés a minta és az Aranykönyv alapján (MNB, 2017)

A minta alapján meghatározott robusztus átlagot figyelembe véve összesen 10 nagy, illetve 30 kicsi, részvénytársasági formában működő hitelintézet van hazánkban. A nagy bankok 70 százalékától, míg a kis bankok 27 százalékától érkezett válasz. A minta a hitelintézetek számát tekintve összesen 38 százalékát, míg a mérlegföösszeget tekintve 64 százalékát fedi le a teljes sokaságnak. 


\section{A 2017-ben egyedi beszámolás szintjén alkalmazott számviteli szabályrendszer}

A mintában szereplő hitelintézeteket az IFRS 9 áttérés előtti, 2017.12.31-ével befejeződő üzleti évre vonatkozó, egyedi éves beszámolójukban alkalmazott számviteli szabályrendszer szerint is csoportosítottuk. Ennek az alapján a 2017-es évben 7 hitelintézet az IFRS-eket, míg 8 hitelintézet a magyar számviteli szabályokat alkalmazta.

A csoportosítást szintén megvizsgáltuk a teljes sokaságra nézve is, amelynek az eredménye a következő táblázatban látható.

\section{2. táblázat}

A sokaság lefedettsége a 2017-ben egyedi beszámolás szintjén alkalmazott számviteli szabályrendszer szerint

\begin{tabular}{|c|c|c|c|c|c|c|}
\hline & \multicolumn{2}{|c|}{ IFRS } & \multicolumn{2}{|c|}{ HAS } & \multicolumn{2}{|c|}{ Összesen } \\
\hline & $\begin{array}{l}\text { Bankok } \\
\text { száma }\end{array}$ & $\begin{array}{l}\text { Mérleg- } \\
\text { föösszeg } \\
\text { (Mrd Ft) }\end{array}$ & $\begin{array}{l}\text { Bankok } \\
\text { száma }\end{array}$ & $\begin{array}{l}\text { Mérleg- } \\
\text { föösszeg } \\
\text { (Mrd Ft) }\end{array}$ & $\begin{array}{l}\text { Bankok } \\
\text { száma }\end{array}$ & $\begin{array}{l}\text { Mérleg- } \\
\text { föösszeg } \\
\text { (Mrd Ft) }\end{array}$ \\
\hline Minta & 7 & 15726 & 8 & 4435 & 15 & 20161 \\
\hline Aranykönyv & 12 & 19755 & 28 & 11654 & 40 & 31409 \\
\hline $\begin{array}{l}\text { Minta/Arany- } \\
\text { könyv }\end{array}$ & $58 \%$ & $80 \%$ & $29 \%$ & $38 \%$ & $38 \%$ & $64 \%$ \\
\hline
\end{tabular}

Forrás: saját szerkesztés a minta és az Aranykönyv alapján (MNB, 2017)

A táblázat alapján látható, hogy 2017-ben egyedi beszámolás szintjén összesen 12 részvénytársasági formában müködő hitelintézet tért át az IFRS-ek alkalmazására, míg 28 hitelintézet még a magyar számviteli szabályok szerint készítette el a pénzügyi kimutatásait. A kérdőívet az IFRS-eket alkalmazók 58 százaléka és a HAS-t alkalmazók 29 százaléka töltötte ki, amely megoszlás a mérlegföösszeget tekintve az előbbi csoportnál 80 százalékot, míg az utóbbinál 38 százalékot jelent.

\section{Az IFRS 9 áttérés előtti IFRS-beszámolási kötelezettség}

A hitelintézeti szektor jelentős része már az IFRS 9-re történő áttérés, azaz 2018 előtt is készített IFRS alapú konszolidált beszámolót, vagy azzal azonos tartalmú jelentéscsomagot, amely azonban nem feltétlenül eredményezte azt, hogy az IFRS-ek bevezetése ne jelentett volna nagy kihívást számukra. 2006-ban a Pénz- 
ügyi Szervezetek Állami Felügyeletes (továbbiakban: PSZÁF) 38 hitelintézet bevonásával készített felmérést, amely alapján mindössze 2 banknak volt elkülönült, egyedi IFRS-analitikája, 13 bank azonban a magyar számviteli adatok átforgatásával állította elő az IFRS-adatokat, míg 3 bank a két módszer kombinációját alkalmazta. Ehhez hasonlóan egy 2012-ben végzett KPMG-felmérésben szereplő 11 hitelintézet közül 6 bank rendelkezett IFRS-szintü analitikus nyilvántartással. Emellett a konszolidált beszámolás szintjén, föleg a magyar adatok átforgatása során feltételezhetően számos egyszerüsítést alkalmaztak a hitelintézetek, például egy hitelfelvétel amortizált bekerülési értékét nem az effektív kamatláb módszerrel, hanem a magyar könyv szerinti érték és a felhalmozott nominális kamat összegeként határozták meg. Ezek alapján feltételezhető, hogy azoknak a hitelintézeteknek is jelentős fejlesztésekre volt szükségük, amelyeknek már az IFRS-ek bevezetése előtt is volt valamilyen IFRS-beszámolási kötelezettsége (Gulyás, 2017). A felmérések óta sok év telt el, ezért a kérdőívvel mi is feltérképeztük, hogy a mintában szereplő hitelintézetek közül mennyien készítettek az IFRS 9 standardra történő áttérés előtt IFRS-beszámolót vagy azzal azonos tartalmú jelentést, illetve hogy az ehhez szükséges adatokat milyen módon állították elö.

A 2017-es évben a magyar számviteli rendszert alkalmazó 8 hitelintézet közül 3 hitelintézet készített az anyavállalat kérésére IFRS-jelentéscsomagot, ezen belül 2 hitelintézet elkülönült, egyedi IFRS-analitikával, míg 1 bank a magyar számviteli adatok összevont, becsléssel történő átforgatásával állította elő a szükséges adatokat. Emellett a korábban IFRS-eket alkalmazók kivétel nélkül elkülönült IFRS-analitikával rendelkeztek. Összességében az áttérés előtt a mintában szereplő hitelintézetek 60 százalékának volt egyedi IFRS-analitikája, amely a korábbi felmérésekhez képest magasabb arányt mutat.

\subsection{A magyarázó változók közötti kapcsolatok}

Feltételezhető volt, hogy a hitelintézetek különféle ismérvek szerinti megoszlása között szoros kapcsolat van, ezért a 4.3. Az eredményváltozók értékelése részben a válaszokat elegendő lehet az egyik szempont szerinti csoportosítás mentén elemezni. Ennek érdekében az SPSS-rendszerben a Cramer-féle asszociációs együttható segítségével megvizsgáltuk a kiválasztott csoportok közötti kapcsolat erősségét.

3 Ma már az MNB hatáskörébe tartozik az ellenőrzés (Gulyás, 2017). 


\section{3. táblázat}

\section{A magyarázó változók közötti kapcsolatok}

\begin{tabular}{cccc}
\hline Cramer's V & Méret & 2017 - IFRS/HAS & $\begin{array}{c}\text { IFRS-beszámoló / } \\
\text { jelentés } \\
\text { az IRFS 9 előtt }\end{array}$ \\
Méret & - & 0,464 & 0,378 \\
2017 - IFRS/HAS & 0,464 & - & 0,661 \\
$\begin{array}{c}\text { IFRS-beszámoló / } \\
\text { jelentés } \\
\text { az IFRS 9 elött }\end{array}$ & 0,378 & 0,661 & - \\
\hline Átlag & 0,421 & 0,563 & 0,520 \\
\hline
\end{tabular}

Forrás: saját szerkesztés

A hitelintézetek mérete és az IFRS 9 áttérés előtti IFRS-beszámolási kötelezettség között az együttható értéke o,378, amely a közepesnél gyengébb kapcsolatot mutat. A hitelintézetek mérete és a 2017-ben egyedi beszámolás szintjén alkalmazott számviteli szabályrendszer között közepes kapcsolat (együttható értéke 0,464), míg az áttérés előtt alkalmazott számviteli szabályrendszer és a korábbi IFRSbeszámolási kötelezettség között a közepesnél erősebb kapcsolat van (az együttható értéke 0.661). Az együtthatók átlagai alapján a 2017-ben egyedi beszámolás szintjén alkalmazott számviteli szabályrendszer szoros kapcsolatban áll a másik két változóval, tehát elegendő egy szempont alapján elemezni az eredményváltozókat kiváltó kérdéseket, így a továbbiakban csak a 2017-es évben egyedi beszámolás szintjén alkalmazott számviteli szabályrendszer szerinti csoportosítás mentén vizsgáljuk a válaszokat.

\section{Az eredményváltozók értékelése}

Az eredményváltozókat kiváltó kérdéseket az alábbi 3 témakör szerint csoportosítottuk:

- az áttérés általános jellemzői;

- kihívások;

- előnyök és hátrányok. 


\subsubsection{Az áttérés általános jellemzői}

Az IFRS 9 standardra történő áttérés körülményei között felmértük, hogy a válaszadók elsődlegesen mely információforrásokból ismerték meg az IFRS 9 standard előírásait, igénybe vettek-e külső szakértői, tanácsadói segítséget, készítettek-e GAP-elemzést, illetve határidőre sikerült-e megvalósítaniuk az áttérési projektet.

\section{Információforrások}

A válaszadók 5-ös skálán értékelték, hogy az IFRS 9 elöírásainak megismeréséhez milyen gyakran használták a megadott információforrásokat. A válaszokat a 27 kitöltő véleménye alapján, tehát nem bankonként összesítve vizsgáltuk. Az így kapott átlagokat tekintve az IFRS 9 standard elolvasása, a tanfolyamokon való részvétel, illetve az anyavállalati tájékoztatás minősült a legjelentősebb információforrásnak, azonban a legmagasabb átlag is 4-es érték alatt maradt.

A 2017-ben alkalmazott számviteli szabályrendszer szerinti csoportokban felállított sorrend három esetben tért el jelentősen egymástól. A sorrend alapján az IFRS-eket már korábban is alkalmazó hitelintézetek szakértői leginkább az anyavállalattól kapott tájékoztatásból, illetve az IFRS 9 standard elolvasásából ismerkedtek meg az IFRS 9 elöírásaival, míg szakkönyveket ritkán vagy egyáltalán nem használtak. Ezzel szemben a korábban a magyar számviteli szabályrendszert alkalmazók számára a tanfolyamok, a szakkönyvek, illetve az IFRS 9 standard jelentették az elsődleges információforrásokat, amellyel feltételezhetően az anyavállalati tájékoztatás hiányát pótolták.

\section{Külső szakértő/tanácsadó}

A felmérések alapján látható, hogy a vállalatoknak az IFRS áttérési projekt bizonyos szakaszaiban szükségük volt arra, hogy külső szakmai segítségre tudjanak támaszkodni, ezért a kérdőívben mi is felmértük, hogy a hitelintézetek hány százaléka élt ezzel a lehetőséggel. A mintában szereplő hitelintézetek az IFRS 9 áttérési projekt során kivétel nélkül igénybe vettek külső szakértői vagy tanácsadói segítséget, tehát a gyakorlat a korábbi kutatások alapján megfogalmazott várakozásainkat meghaladta.

\section{GAP-elemzés}

A válaszok alapján a bankok legnagyobb része számviteli szabályozásra, illetve IT-rendszerre, míg 40 százalékuk adózással összefüggő kérdésekre és működési folyamatokra, kontrollokra is készített hatásvizsgálatot. Ez megegyezett a várakozásainkkal, hiszen az IFRS 9 standard jelentős változtatásokat hozott a pénzügyi instrumentumok szabályozásában, amihez természetesen elengedhetetlen a számviteli hatásvizsgálat. Emellett az IFRS 9 „újdonságai” (gondoljunk például a koráb- 
ban magyar számviteli szabályokat alkalmazók esetén az effektív kamatláb módszerére) jelentős IT-fejlesztéseket igényeltek, ezért az IT-hatások, valamint a belső kontrollokra gyakorolt hatások felmérése is fontos volt a hitelintézetek számára.

\section{Határidőtartás}

A felmérésben szereplő hitelintézetek kétharmada, azaz 10 bank már a 2016-os évben elindította az áttérési projektet az IFRS 9 standardra, amelyet öten a tervezett időn belül, 12-24 hónap alatt sikeresen befejeztek. Ezzel szemben egy - a nagyok csoportjába tartozó - bank az áttérési projekt megvalósítását jelentősen alulbecsülte, 6-12 hónap helyett több mint 24 hónap alatt fejezte be ténylegesen a projektet. Ez a bank csak a számviteli szabályokra készített GAP-elemzést, tehát feltételezhetően azért becsülte jelentősen alul a projekt hosszát, mert nem végzett teljes körü hatáselemzést, ez pedig alátámasztja a PwC-felmérésének eredményét, amely szerint az áttérés megvalósításának hatékonysága nagymértékben összefügg a hatáselemzés elkészítésére fordított idővel (Kökény, 2017). További 4 bank a felmérés időpontjában még nem fejezte be az áttérési projektet. A mintában mindössze egy olyan hitelintézet szerepelt, amely 1 év halasztást kapott az IFRS-ek bevezetésére. Emellett azon hitelintézetek közül, amelyek a 2017-es évben indították el az áttérési projektet, négyen 12-24 hónap alatt valósították meg az áttérést, ami a projekt indításához viszonyítva szintén azt mutatja, hogy a 2018-as évre még maradtak folyamatban lévő feladataik.

Összességében a mintában szereplő hitelintézetek 60\%-ának, azaz 9 hitelintézetnek nem sikerült 2018. január 1-jéig befejeznie az IFRS 9 standardra történő áttérési projektet.

A válaszokból azonban az nem derül ki egyértelmüen, hogy azoknál a hitelintézeteknél, amelyek még nem fejezték be az áttérési projektet, milyen mértékü feladatok húzódtak át a 2018-as évre. További kutatást igényelne, esetleg interjúk készítésével tárhatnánk fel, hogy vajon csak néhány kisebb feladat maradt-e az IFRS 9 standard hatályba lépésének évére, vagy ennél rosszabb eset áll fenn, és alapvető funkciók hiányoznak.

\subsubsection{Kihívások}

Annak érdekében, hogy a hitelintézetek előtt álló, az IFRS 9 standard bevezetésével kapcsolatos kihívásokat is megismerjük, a kérdőívben a következő három kérdéskör mentén mértük fel a válaszadók tapasztalatait:

- általános kihívások;

- számviteli kihívások;

- IT-kihívások. 
Feltételezhetően azok a hitelintézetek, amelyek számára a 2018-as év az IFRS-ek és az IFRS 9 standard együttes bevezetését jelentette, nagyobb kihívásként élték meg az új standard elöírásainak befogadását, mint amelyek már az áttérés előtt az IFRS-ek szerint készítették el egyedi beszámolójukat. A feltételezés alátámasztása érdekében a kapott válaszokat a 2017-es évben alkalmazott számviteli szabályrendszer szerinti csoportosítás mentén is vizsgáljuk.

\section{Általános kihívások}

A válaszadók 5-ös skálán értékelték, hogy milyen szinten érintették őket az általunk felsorolt kihívások. A válaszok alapján a három legnagyobb általános kihívást az IT-rendszer kiforratlansága, a nagy információigény (kötelező jelentések), illetve az időhiány jelentette. Ezen kívül a válaszadók a hazai szabályozás kiforratlanságát, a tapasztalat hiányát és a megfelelő számú, képzett IFRS-szakember hiányát is a teljes átlaghoz képest nagyobb problémának tekintették. A GAPelemzés hiánya jelentette a legkisebb kihívást, ami nem meglepő, hiszen a mintában szereplő hitelintézetek közül 13-an biztosan készítettek GAP-elemzést, míg két banktól „Nem tudom” válasz érkezett. Azonban érdekes módon az áttérési projekt hosszának alulbecslése sem jelentett kiemelkedő problémát, pedig a válaszok alapján a hitelintézetek 60 százaléka nem tudta befejezni a projektet az IFRS 9 standard hatályba lépéséig.

Korábban azzal a feltételezéssel éltünk, hogy a 2017-ben magyar számviteli szabályrendszert alkalmazó hitelintézetek jelentősen magasabbra fogják értékelni a kihívásokat, hiszen nekik nemcsak az IFRS 9 standard újdonságait, többek között a besorolás, az értékvesztés és a fedezeti elszámolás változásait, hanem az IFRSek alapvető logikáját (például: effektív kamatláb módszer, valós értékelés) is meg kellett ismerniük. A felmérés eredménye valóban azt mutatja, hogy a korábban HAS-t alkalmazók összességében magasabbra értékelték a kihívásokat, azonban az eltérés a vártnál lényegesen alacsonyabb. Mindkét csoport számára az ITrendszer kiforratlansága jelentette a legnagyobb kihívást, bár eltérő mértékben. A korábban HAS-t alkalmazó hitelintézetek IT-rendszerei feltételezhetően nem voltak felkészítve az alapvető IFRS-kalkulációkra (például az effektív kamatláb módszertanra, valós értékelésre) sem, ezért számukra nagyobb kihívást jelenhetett ezeknek a funkcióknak a fejlesztése és implementálása. Ezzel szemben a 2017ben már IFRS-eket alkalmazók számára a meglévő funkciók javítása, bővítése, továbbá az értékvesztéssel, illetve a fedezeti számvitellel kapcsolatos változtatások jelenthettek nagy kihívást.

A csoportonként felállított sorrendben kiemelkedő eltérés tapasztalható a szabályozás kiforratlanságára adott válaszok esetén. Miközben a 2017-ben már IFRSeket alkalmazó hitelintézetek az egyik legnagyobb kihívásnak ítélték meg a szabályozás - azaz az IFRS 9 standard elöírásainak - kiforratlanságát, addig ez a 
kihívás a korábban HAS-t alkalmazó bankoknál az 5. helyre szorult, az átlagok közötti különbségben azonban nincs jelentős eltérés, tehát összességében nagy problémát jelentett mindenki számára. A sorrendbeli eltérés feltételezhetően arra vezethető vissza, hogy a HAS-t alkalmazóknál nagyobb mértékben jelentkezett a tapasztalat, illetve a tudás hiánya, ezáltal valószínűleg a szabályozás kiforratlanságát kisebb problémának érzékelték. Emellett a korábban HAS-t alkalmazó hitelintézeteknek nagy kihívást jelentett az idő hiánya is: jellemzően kis bankok tartoznak ebbe a csoportba, ezért feltételezhetően az alacsonyabb létszám mellett kevésbé tudták megosztani a feladatokat.

A 2017-ben alkalmazott számviteli szabályrendszer szerepének elemzésén túl megvizsgáltuk azt is, hogy a hitelintézetek határidőtartása vajon hatással volt-e a válaszokra. Nem meglepő módon azok a hitelintézetek, amelyek az IFRS 9 standard hatályba lépéséig nem fejezték be az áttérési projektet, összességében magasabbra értékelték a kihívásokat; ezen belül különösen a GAP-elemzés, a tapasztalat hiánya és az áttérési projekt hosszának alulbecslése esetén mutatkozott jelentős eltérés. A válaszok alapján valószínűleg ezek a hitelintézetek nem végeztek teljes körü GAP-elemzést, ennek eredményeképpen alulbecsülték az áttérési projekt hosszát, amely végül oda vezetett, hogy a kitűzött határidőket nem tudták tartani.

\section{Számviteli kihívások}

Az IFRS 9 standard bevezetése alapjaiban megváltoztatta a pénzügyi instrumentumok besorolásának, valamint a hazai számviteli szabályokról áttérők számára azok értékelésének módját, és jelentős változásokat hozott az értékvesztés és a fedezeti számvitel területeken is. Annak érdekében, hogy felmérjük: a mintában szereplő hitelintézetek számára mely számviteli terület jelentette a legnagyobb kihívást, a kérdőívben külön kérdésként szerepelt a számviteli kihívások értékelése.

$\mathrm{Az}$ értékelések átlaga alapján a három legnagyobb kihívást az értékvesztés meghatározása, az SPPI-teszt, valamint az adózással összefüggő kérdések jelentették. Ez összhangban áll a szekunder kutatás eredményeivel, ahol a Deloitte tapasztalatai is azt mutatták, hogy a pénzügyi eszközök besorolása és az értékvesztésmódszertan meghatározása nehézségeket jelent a vállalatok számára (Veszprémi et al., 2018). A kapott eredmények egybecsengenek a Big4-felmérés azon eredményével is, mely szerint az adózási jogszabályok IFRS-ekkel történő összehangolása is kiemelten fontos terület (Bartha et al., 2014). Emellett átlagon felüli kihívást jelentett a válaszadók számára a támogatott ügyletek kezelése. A válaszok alapján a költségek, jövőbeli cash flow-elemek becslése is nehézséget jelent, hiszen az üzletnek már az ügylet kezdetekor előre meg kell becsülnie a várható cash flow-kat. A válaszadók a fedezeti számvitelt tekintették a legkisebb kihívásnak, amelynek hátterében egyrészről az IAS 39 standard szabályaihoz képest az IFRS 9 standard 
egyszerübb szabályai állhatnak, másrészről az, hogy áttérés előtt már a hitelintézetek kétharmada valamilyen módon alkalmazta a fedezeti elszámolást.

A 2017-es évben IFRS-eket alkalmazó hitelintézetek számára az értékvesztés jelentette a legnagyobb kihívást, ezt a témakört kivétel nélkül 5-ösre értékelték a számviteli szakértők. Ezzel szemben a korábban HAS-t alkalmazó hitelintézetek mind sorrendben, mind értékelésben jelentősen kisebb kihívásnak ítélték meg az értékvesztést. Ennek feltételezhetően az lehet az oka, hogy ez utóbbi csoport 75 százaléka kis bank, amelyek korábban csak a sztenderd módszert alkalmaztak a tőkekövetelmények kiszámítására, így a költség-haszon elv szem előtt tartása mellett az áttérést követően is valószínűleg egyszerűbb értékvesztési modelleket alakítottak ki. A támogatott ügyletek témaköre is megosztotta a válaszadók véleményét. Miközben a korábban IFRS-eket alkalmazó hitelintézetek a második legnagyobb kihívásnak gondolták, addig a HAS-t alkalmazóknál a sorrend végén szerepel a támogatott ügyletek kezelése. Ezzel szemben a korábban HAS-t alkalmazóknak a legnagyobb kihívást az adózással összefüggő kérdések jelentették, hiszen számukra a 2018-as év az IFRS 9 standard és az IFRS-ek együttes bevezetését jelentette, ami feltételezhetően háttérbe szorította a speciális ügyletek kezelésének problémáját.

\section{IT-kihívások}

Az IFRS 9 bevezetése a számviteli kihívások mellett jelentős IT-fejlesztéseket jelentett a hitelintézetek számára, ezért a kérdőívben külön felmértük, hogy az IFRS 9-hez szükséges adatok előállításának mekkora része valósul meg IT-rendszerben, illetve mely fejlesztések milyen mértékű nehézséget okoztak a válaszadók számára.

A válaszok alapján nem meglepő módon a legnagyobb IT-kihívást a kötelező jelentések fejlesztése jelentette, hiszen a KPMG tapasztalatai szerint az IFRS-ek bevezetése egy-egy hitelintézetnél megközelítőleg 80-10o jelentést is érinthet (Veit, 2018), amelyek közül a válaszadók becsléseit alapul véve a jelentések 51-75 százalékának előállítása valósul meg IT-rendszerben. Ezen kívül az IFRS 9 bevezetéséhez szükséges adatok előállítása az értékvesztés és a valós értékelés területein is jelentős fejlesztéseket eredményezett, miközben a fedezeti számvitel az IT-kihívások tekintetében is utolsó helyen szerepel.

Feltételezhető volt, hogy a korábban magyar számviteli rendszert alkalmazó hitelintézetek magasabbra értékelték az IT-kihívásokat, hiszen az alapvető IFRSkalkulációk ismeretlenek voltak a számukra, ezért a válaszokat a 2017-ben alkalmazott számviteli szabályrendszer csoportosítása mentén is megvizsgáltuk.

Összességében a 2017-es évben magyar számviteli szabályrendszert alkalmazó hitelintézetek szakértői jelentősen magasabbra értékelték az IT-kihívásokat, mint az IFRS-eket alkalmazók, ami megegyezik a korábbi feltételezéseinkkel. Az utób- 
bi csoport számára az értékvesztés, a valós értékelés és a kötelező jelentések elkészítésének automatizálása jelentette a legnagyobb kihívást, míg a korábban magyar számviteli szabályrendszert alkalmazó hitelintézetek szakértői számára a kötelező jelentések és a fedezeti számvitel-elszámolás mellett az alapvető értékelést jelentő amortizált bekerülési érték számítása is megjelent. Nem meglepő, hogy a korábban HAS-t alkalmazó hitelintézetek szakértőinek nagyobb kihívást jelentett az amortizált bekerülési érték számításának az IT-rendszerbe történő implementálása, hiszen számukra szakmailag is újdonságnak számított az effektív kamatláb módszere.

\subsubsection{Előnyök és hátrányok}

A kérdőíves felmérés során feltártuk, vajon a hitelintézetek szakértői, akik nap mint nap részesei voltak az IFRS-ek implementálásának, azon belül kiemelten az IFRS 9 áttérési projektnek, előnynek vagy hátránynak látják az IFRS 9 bevezetését. A 2017-ben egyedi beszámolás szintjén alkalmazott számviteli szabályrendszer nem volt hatással az eredményekre, ezért az előnyök és hátrányok értékelését csak összességében elemezzük.

\section{Előnyök}

A válaszadók a kérdőívben előre felsorolt előnyöket 5-ös skálán értékelték, amelynek eredménye a következő táblázatban látható:

\section{5. táblázat}

\section{Előnyök értékelése}

Átlag/Értékelés

Üzleti céloknak megfelelőbb számviteli kezelés

Rugalmasabb átsorolás

Kedvezőbb jövedelmi helyzet

Adminisztrációs teher csökkentése

(magyar számviteli adatokra már nincs szükség)

Kedvezőbb adóterhelés

IFRS-beszámoló összeállításának alacsonyabb időigénye

Összesen

2,31

Megjegyzés: 5-ös skála értelmezése: 5: „nagy előnyt jelentett”, 1: „nem jelentett előnyt”. Forrás: saját szerkesztés 
A táblázat alapján az első szembetűnő információ, hogy mindössze 2.31 az előnyök értékelésének átlaga, ami meglehetősen alacsonynak tünik a korábbi felmérések eredményeihez képest. Például a válaszadók az adminisztrációs teher csökkenését sem tekintették nagy előnynek, miközben a várakozások azt mutatták, hogy a párhuzamos könyvek vezetésének megszüntetése az adminisztrációs terhek jelentős csökkenését fogja eredményezni. Ennek oka feltételezhetően az lehet, hogy bizonyos magyar adatok előállítására - például hitelek esetén az ügyfelekkel való elszámoláshoz - továbbra is szükség van.

A válaszadók a „legnagyobb” előnynek - bár csupán 2.83-as átlaggal - az üzleti céloknak megfelelőbb számviteli kezelést tekintették. Ez nem meglepő, hiszen gondoljunk a pénzügyi eszközök besorolásához szükséges üzleti modell vizsgálatára vagy a fedezeti elszámolás 80-125 százalékos szabályának eltörlésére, amely azt mutatja, hogy az IFRS 9 standard célja a pénzügyi instrumentumok számviteli elszámolásának a hozzáigazítása az üzleti, illetve a kockázatkezelési célokhoz.

\section{Hátrányok}

Az előnyök mellett a válaszadók az IFRS 9 standard bevezetésének hátrányait is értékelték, amelyeket a következő táblázatban foglaltunk össze:

\section{6. táblázat}

\section{Hátrányok értékelése}

Átlag / Értékelés

Átálláshoz kapcsolódó magas, egyszeri költségek 4,08

IFRS-beszámoló összeállításának magasabb időigénye

Jövedelmezőség eltérő értelmezése

Portfólió összetételének megváltozása

Kedvezőtlenebb adóterhelés

Kedvezőtlenebb jövedelmi helyzet

Magyar számviteli adatok továbbra is szükségesek

Megjegyzés: 5-ös skála értelmezése: 5: „nagy előnyt jelentett”, 1: „nem jelentett előnyt”. Forrás: saját szerkesztés

A táblázatban látható, hogy a hátrányok értékelésének átlaga 3,28, amely jelentős mértékben meghaladja az előnyök átlagát, ezzel alátámasztva azt, hogy az első 
évben a hitelintézetek inkább negatívan ítélték meg az áttéréssel járó feladatokat. A legnagyobb hátránynak az IFRS 9 bevezetéséhez kapcsolódó magas egyszeri költségek bizonyultak, ami összhangban van a szekunder kutatás eredményeivel. Emellett a válaszadók az IFRS-beszámoló összeállításának magasabb időigényét tekintették nagy kihívásnak, ami nem meglepő, hiszen az IFRS alapú beszámolókhoz sokkal részletesebb kiegészítő megjegyzések szükségesek, amelyeket az első években várhatóan nehezebb is lesz elkészíteniük a számviteli szakértőknek (Rakó, 2018). A jövedelmezőség eltérő értelmezését is átlagnál nagyobb kihívásnak értékelték a válaszadók, hiszen az IFRS-ek bevezetésével a valós értéken történő értékelés az eredmény nagyobb változékonyságához vezet, amely feltételezhetően szükségessé teszi a hitelintézetek számára az ösztönzési rendszerek átalakítását is (Bodor et al., 2017). Végül az adózás kérdéskörét inkább hátránynak tekintették a válaszadók, feltételezhetően az eredmény változékonyságának következtében, azonban a jogalkotás alapvetően törekedett arra, hogy az IFRS-ek bevezetése ne okozzon lényeges eltérést az adózás szempontjából (Lipták, 2018).

\section{KÖVETKEZTETÉS}

Tanulmányunkban a hitelintézetek szakértőinek az IFRS 9 - Pénzügyi instrumentumok standarddal kapcsolatos tapasztalatainak felmérését tűztük ki célul, amelynek érdekében kérdőíves kutatást készítettünk.

A kutatás során arra kerestük a választ, hogy a hitelintézetek szakértői hogyan vélekednek az IFRS 9 áttérési projekt sikerességéről, milyen kihívásokat jelentett számukra az új standard elöírásainak implementálása, valamint milyen előnyöket és hátrányokat társítanak az áttéréshez. Érdekes módon a kutatásban részt vevő hitelintézetek 60 százalékának nem sikerült befejeznie az áttérési projektet 2018. január 1-jéig, azonban további kutatást igényelne annak felmérése, hogy milyen mértékü feladatok húzódtak át a 2018-as évre, vajon képesek voltak-e a folyamatban lévő feladatok ellenére az MNB-nek írt jelentéseket elkészíteni. A kérdések többségében azt tapasztaltuk, hogy a válaszok között jelentős különbség van aszerint, hogy a válaszadók bankja az áttérés előtt készített-e már IFRS-ek szerinti egyedi beszámolót vagy sem. Így az előbbi csoport mindenütt alacsonyabbra értékelte a kihívásokat, és e kihívások sorrendje is eltérő volt.

A kutatásban résztvevők számára az IT-rendszer kiforratlansága jelentette a legnagyobb kihívást. Feltételezhetően a korábban sem IFRS-beszámolót, sem IFRS anyavállalati jelentéscsomagot nem készítő hitelintézetek IT-rendszerei nem voltak felkészítve az alapvető IFRS-kalkulációkra sem (például az effektív kamatláb módszertan, valós értékelés), ezért számukra nagy problémát jelenhetett ezeknek a funkcióknak a fejlesztése és implementálása. Ezzel szemben a korábban már 
IFRS-eket alkalmazók számára vélhetően a meglévő funkciók javítása, bővítése, továbbá az értékvesztéssel, illetve a fedezeti számvitellel kapcsolatos változtatások jelenthettek nagy kihívást.

A két csoport válaszai közötti eltérést a számviteli kihívásoknál is tapasztaltuk mind a sorrendet, mind pedig az átlagos értékeket tekintve. A 2017-es évben IFRS-eket alkalmazó hitelintézetek számára az értékvesztés jelentette a legnagyobb kihívást, amely témakört kivétel nélkül 5-ösre értékelték a számviteli szakértők. Ezzel szemben a korábban HAS-t alkalmazó hitelintézetek mind sorrendben, mind értékelésben jelentősen kisebb kihívásnak ítélték meg az értékvesztést. Ezenkívül a korábban IFRS-eket alkalmazó hitelintézetek a támogatott ügyletek kezelését a második legnagyobb kihívásnak gondolták, viszont a HAS-t alkalmazóknál a sorrend végén szerepel a támogatott ügyletek kezelése. Ezzel szemben a korábban HAS-t alkalmazóknak a legnagyobb kihívást az adózással összefüggő kérdések jelentették, hiszen számukra a 2018-as év az IFRS 9 standard és az IFRSek együttes bevezetését jelentette, ami feltételezhetően háttérbe szorította a speciális ügyletek kezelésének problémáját.

Végül a kérdőívben az általunk felsorolt előnyök és hátrányok 5-ös skálán történő értékelésének eredménye nem igazolta az IFRS-ek és az IFRS 9 bevezetésének elvárt előnyeit, hiszen a válaszadók összességében jelentősen alacsonyabbra értékelték az előnyöket, mint a hátrányokat. Ennek az alapján arra a következtetésre jutottunk, hogy a 2018-as év még „tanulóévet” jelentett, illetve még jelent is a hitelintézetek számára, hiszen ez időszak alatt az új szabályok implementálása jelentős kihívást jelentett a kutatásban résztvevőknek, aminek következtében egyelőre a válaszadók számára az IFRS 9 standard bevezetésének hátrányai a hangsúlyosabbak. Néhány év múlva, amikor már elegendő tapasztalatot szereztek a hitelintézetek, érdemes lenne újból felmérni, vajon változott-e az idő elteltével a szakértők véleménye az IFRS 9-re történő áttéréssel kapcsolatban. 


\section{FÜGGELÉK}

1. melléklet

\section{Kérdőív}

Alapadatok:

*kötelező

1. Kérem, adja meg, melyik hitelintézetnél dolgozik: *

2. Kérem, válassza ki, milyen területen dolgozik: *

$\square$ Számvitel

$\square \quad$ Kötelező jelentések

$\square$ Back office

$\square$ Kockázatkezelés

$\square \quad$ Front office

$\square \quad$ Projektvezetés

$\square \quad$ IT

$\square$ Egyéb:

\section{Kérdések}

1. Melyik évben térnek/tértek át az IFRS 9 alkalmazására?

$\square$ 2017-es évben

$\square$ 2018-as évben

$\square \quad$ Még nem tértünk át

$\square$ Nem tudom

2. IAS 39-ről vagy magyar számviteli rendszerről térnek/tértek át?
$\square \quad$ IAS 39
$\square$ Magyar számviteli rendszer
$\square \quad$ Nem tudom

3. Az áttérés előtt készítenek/készítettek-e a magyar számviteli beszámoló mellett egyedi IFRS-beszámolót vagy azzal azonos tartalmú jelentést?

$\square$ Igen, az anyavállalat kérésére IFRS jelentéscsomagot

$\square \quad$ Nem

$\square \quad$ Nem tudom

$\square$ Egyéb: 
4. Az áttérés előtt az IFRS-jelentéscsomaghoz milyen módon állítják/állították elő az adatokat?

$\square \quad$ Elkülönült, egyedi IFRS-adatokkal

$\square$ Magyar számviteli adatok összevont, becsléssel történő átforgatásával

$\square \quad$ Nem tudom

$\square$ Nem készítünk/készítettünk IFRS-jelentéscsomagot

$\square$ Egyéb:

5. Az áttérést követően az IFRS-beszámolóhoz milyen módon állítják elő/állítják majd elő az adatokat?

$\square \quad$ Elkülönült, egyedi IFRS-adatokkal

$\square \quad$ Magyar számviteli adatok egyedi analitikával történő átforgatásával

$\square$ Magyar számviteli adatok összevont, becsléssel történő átforgatásával

$\square \quad$ Nem tudom

$\square$ Egyéb:

6. Kérem, 5-ös skálán értékelje, hogy az IFRS 9 előírásainak megismeréséhez milyen gyakran használja/használta az alábbi információforrásokat ( 1 - nem használtam, 5 - gyakran használtam):

\begin{tabular}{|lllllll|}
\hline & 1 & 2 & 3 & 4 & 5 & Nem tudom \\
\hline IFRS 9 standard elolvasása & & & & & & \\
\hline Tanfolyamok & \\
\hline Konferenciák & \\
\hline Anyavállalati tájékoztatás & \\
\hline Folyóiratok & & & & & \\
\hline Hírlevelek & & & \\
\hline Szakkönyvek
\end{tabular}

7. Az IFRS 9 áttérési projekt során külső szakértő/tanácsadó segítségét is igénybe veszik/vették?

$\square \quad$ Igen

$\square \quad$ Nem

$\square \quad$ Nem tudom 
8. Kérem, válassza ki, mely területekre készítettek GAP-elemzést az IFRS 9 áttérési projekt elején (több választ is jelölhet):

$\square$ Számviteli szabályozás

$\square \quad$ IT-rendszer

$\square \quad$ Müködési folyamatok, kontrollok

$\square$ Adózással összefüggő kérdések

$\square$ Nem készítettünk GAP-elemzést

$\square \quad$ Nem tudom

$\square$ Egyéb:

9. Melyik évben indították el az IFRS 9 áttérési projektet?

$\square$ A 2016-os év előtt

$\square$ A 2016-os évben

$\square$ A 2017-es évben

$\square$ A 2018-es évben

$\square \quad$ Még nem indítottuk el

$\square \quad$ Nem tudom

10. Az IFRS 9 áttérési projekt megvalósítását mennyi időre becsülték?

$\square$ Kevesebb, mint 6 hónap

$\square \quad 6-12$ hónap

$\square$ 12-24 hónap

$\square \quad$ Több, mint 24 hónap

$\square \quad$ Nem tudom

11. Az IFRS 9 áttérési projekt mennyi idő alatt valósult meg?

$\square \quad$ Kevesebb, mint 6 hónap

$\square \quad 6-12$ hónap

$\square \quad$ 12-24 hónap

$\square \quad$ Több, mint 24 hónap

$\square \quad$ Még nem fejeződött be, de a tervezett határidőt tartani tudjuk

$\square$ Még nem fejeződött be, és a tervezett határidőt nem tudjuk tartani

$\square \quad$ Nem tudom 
12. Kérem, 5-ös skálán értékelje az IFRS 9-re történő áttérés kihívásait, problémáit (1 - nem jelent/jelentett kihívást, 5 - nagy kihívást jelent/jelentett):

\begin{tabular}{|lllllll|}
\hline & 1 & 2 & 3 & 4 & 5 & Nem tudom \\
\hline GAP-elemzés hiánya & \\
\hline Áttérési projekt hosszának alulbecslése \\
\hline Idő hiánya a napi feladatok mellett \\
\hline Projektvezető hiánya \\
\hline $\begin{array}{l}\text { Megfelelő számú, képzett } \\
\text { IFRS-szakember hiánya }\end{array}$ \\
\hline Tapasztalat hiánya \\
\hline IT-rendszer kiforratlansága \\
\hline Szabályozás kiforratlansága \\
\hline $\begin{array}{l}\text { Nagy információigény } \\
\text { (kötelező jelentések) }\end{array}$ \\
\hline
\end{tabular}

13. Vannak/voltak-e az IFRS 9-re történő áttérésnek egyéb kihívásai, problémái? Ha igen, kérem, nevezze meg őket:

Egyéb:

14. Az IFRS 9-re történő áttérés előtt alkalmazzák/alkalmazták-e a valós értékelést?
$\square \quad$ Igen
$\square \quad$ Nem
$\square \quad$ Nem tudom

15. Az IFRS 9-re történő áttérés előtt alkalmazzák/alkalmazták-e a fedezeti elszámolást?
$\square \quad$ Igen
$\square \quad$ Nem
$\square \quad$ Nem tudom

16. Az IFRS 9-re történő áttérést követően alkalmazzák/alkalmazzák majd a fedezeti elszámolást?
$\square \quad$ Igen
$\square \quad$ Nem
$\square \quad$ Nem tudom 
17. Kérem, 5-ös skálán értékelje az IFRS 9-re történő áttérés számviteli kihívásait (1 - nem jelent/jelentett kihívást, 5 - nagy kihívást jelent/jelentett):

\begin{tabular}{|c|c|c|c|c|c|c|}
\hline & 1 & 2 & 3 & 4 & 5 & Nem tudom \\
\hline SPPI-teszt & & & & & & \\
\hline Üzleti modell értékelése & & & & & & \\
\hline $\begin{array}{l}\text { Amortizált bekerülési érték } \\
\text { számítása }\end{array}$ & & & & & & \\
\hline $\begin{array}{l}\text { Költségek, } \\
\text { jövőbeni cash flow-elemek becslése }\end{array}$ & & & & & & \\
\hline Valós értékelés & & & & & & \\
\hline Értékvesztés meghatározása & & & & & & \\
\hline Fedezeti számvitel & & & & & & \\
\hline $\begin{array}{l}\text { Támogatott ügyletek kezelése } \\
\text { (például: HIRS) }\end{array}$ & & & & & & \\
\hline Adózással összefüggő kérdések & & & & & & \\
\hline
\end{tabular}

18. Vannak/voltak-e az IFRS 9-re történő áttérésnek egyéb számviteli kihívásai? Ha igen, kérem, nevezze meg őket:

Egyéb:

19. Kérem, 5-ös skálán becsülje meg, hogy Önöknél az alábbi feladatok mekkora része valósul/valósul majd meg IT-rendszeren keresztül:

\begin{tabular}{|c|c|c|c|c|c|c|c|}
\hline & $0 \%$ & $\begin{array}{c}1- \\
25 \%\end{array}$ & $\begin{array}{l}26- \\
50 \%\end{array}$ & $\begin{array}{c}51- \\
75 \%\end{array}$ & $\begin{array}{l}76- \\
99 \%\end{array}$ & $100 \%$ & $\begin{array}{l}\text { Nem } \\
\text { tudom }\end{array}$ \\
\hline $\begin{array}{l}\text { Pénzügyi instrumentumok } \\
\text { besorolása }\end{array}$ & & & & & & & \\
\hline $\begin{array}{l}\text { Amortizált bekerülési } \\
\text { érték számítása }\end{array}$ & & & & & & & \\
\hline Valós érték számítása & & & & & & & \\
\hline Értékvesztés számítása & & & & & & & \\
\hline Fedezeti számvitel & & & & & & & \\
\hline $\begin{array}{l}\text { Támogatott ügyletek } \\
\text { kezelése (például: HIRS) }\end{array}$ & & & & & & & \\
\hline $\begin{array}{l}\text { Pénzügyi instrumentumok } \\
\text { automatikus könyvelése }\end{array}$ & & & & & & & \\
\hline $\begin{array}{l}\text { Kötelező jelentések } \\
\text { elkészítése }\end{array}$ & & & & & & & \\
\hline
\end{tabular}


20. Kérem, 5-ös skálán értékelje az IFRS 9-re történő áttérés IT-kihívásait (1 nem jelent/jelentett kihívást, 5 - nagy kihívást jelent/jelentett):

\begin{tabular}{|c|c|c|c|c|c|c|}
\hline & 1 & 2 & 3 & 4 & 5 & Nem tudom \\
\hline \multicolumn{7}{|l|}{$\begin{array}{l}\text { Pénzügyi instrumentumok } \\
\text { besorolása }\end{array}$} \\
\hline \multicolumn{7}{|l|}{$\begin{array}{l}\text { Amortizált bekerülési érték } \\
\text { számítása }\end{array}$} \\
\hline \multicolumn{7}{|l|}{ Valós érték számítása } \\
\hline \multicolumn{7}{|l|}{ Értékvesztés számítása } \\
\hline \multicolumn{7}{|l|}{ Fedezeti számvitel } \\
\hline \multicolumn{7}{|l|}{$\begin{array}{l}\text { Támogatott ügyletek kezelése } \\
\text { (például: HIRS) }\end{array}$} \\
\hline \multicolumn{7}{|l|}{$\begin{array}{l}\text { Pénzügyi instrumentumok } \\
\text { automatikus könyvelése }\end{array}$} \\
\hline Kötelező jelentések elkészítése & & & & & & \\
\hline
\end{tabular}

21. Vannak/voltak-e az IFRS 9-re történő áttérésnek egyéb IT-kihívásai? Ha igen, kérem, nevezze meg őket:

Egyéb:

22. Kérem, 5-ös skálán értékelje az IFRS 9-re történő áttérés hátrányait (1 - nem jelent hátrányt, 5 - nagy hátrányt jelent):

\begin{tabular}{|c|c|c|c|c|c|c|c|}
\hline & 1 & 2 & 3 & 4 & 5 & $\mathrm{Nem}$ & tudom \\
\hline $\begin{array}{l}\text { IFRS-beszámoló összeállításának } \\
\text { magasabb időigénye }\end{array}$ & & & & & & & \\
\hline $\begin{array}{l}\text { Magyar számviteli adatok } \\
\text { továbbra is szükségesek }\end{array}$ & & & & & & & \\
\hline $\begin{array}{l}\text { Átálláshoz kapcsolódó magas } \\
\text { egyszeri költségek }\end{array}$ & & & & & & & \\
\hline Kedvezőtlenebb adóterhelés & & & & & & & \\
\hline Kedvezőtlenebb jövedelmi helyzet & & & & & & & \\
\hline Jövedelmezőség eltérő értelmezése & & & & & & & \\
\hline $\begin{array}{l}\text { Portfólió összetételének } \\
\text { megváltozása }\end{array}$ & & & & & & & \\
\hline
\end{tabular}


23. Vannak/voltak-e az IFRS 9-re történő áttérésnek egyéb hátrányai? Ha igen, kérem, nevezze meg őket:

Egyéb:

24. Kérem, 5-ös skálán értékelje az IFRS 9-re történő áttérés előnyeit (1 - nem jelent előnyt, 5 - nagy előnyt jelent):

\begin{tabular}{|lllllll|}
\hline & 1 & 2 & 3 & 4 & 5 & Nem tudom \\
\hline $\begin{array}{l}\text { IFRS-beszámoló összeállításának } \\
\text { alacsonyabb időigénye }\end{array}$ & & & & & & \\
\hline $\begin{array}{l}\text { Adminisztrációs teher csökkentése } \\
\text { (magyar számviteli adatokra már } \\
\text { nincs szükség) }\end{array}$ & & & & & & \\
\hline $\begin{array}{l}\text { Üzleti céloknak megfelelőbb } \\
\text { számviteli kezelés }\end{array}$ & & & & & & \\
\hline Rugalmasabb átsorolás & & & & & \\
\hline Kedvezőbb adóterhelés & & & \\
\hline Kedvezőbb jövedelmi helyzet
\end{tabular}

25. Vannak/voltak-e az IFRS 9-re történő áttérésnek egyéb előnyei? Ha igen, kérem, nevezze meg őket:

Egyéb:

26. Kérem, 5-ös skálán értékelje, hogy az áttérési projekt mely fö területek közös munkájával valósul/valósult meg (1 - nem vesz/vett részt a projektben, 5 teljes mértékben részt vesz/vett a projektben):

\begin{tabular}{|c|c|c|c|c|c|c|}
\hline & 1 & 2 & 3 & 4 & 5 & Nem tudom \\
\hline Számvitel & & & & & & \\
\hline Kötelező jelentések & & & & & & \\
\hline Controlling & & & & & & \\
\hline Back office & & & & & & \\
\hline Kockázatkezelés & & & & & & \\
\hline Front office & & & & & & \\
\hline Projektvezetés & & & & & & \\
\hline IT & & & & & & \\
\hline
\end{tabular}




\section{HIVATKOZÁSOK}

Bartha Zsuzsanna - BAlÁzs GÁbor - Boros Judit - Molnár GÁbor (2014): Úton az IFRS felé. https://www.pwc.com/hu/hu/szolgaltatasok/ifrs/uton_az_ifrs_fele.pdf (letöltve: 2018.11.20.).

Bartha Zsuzsanna - Williams, M. - Hevesi Mónika (2015): Az IFRS hazai alkalmazása Öszszefoglaló a felmérés eredményeiről. https://www.ey.com/Publication/vwLUAssets/IFRS_ SURVEY_HUN_JAV_0619/\$FILE/ifrs_HUN_JAV_06_19.pdf (letöltve: 2018.11.20.).

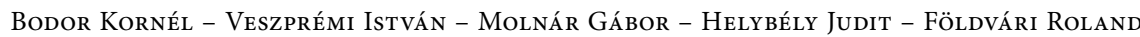
- ÁdÁm ENDre (2017): Összefoglaló jelentés a 2017. évi IFRS-felmérés eredményeiről. https:// www2.deloitte.com/content/dam/Deloitte/hu/Documents/audit/hu-audit-IFRS-jelentes-2017. pdf (letöltve: 2018.11.20.).

GulYÁs Éva (2017): IFRS-ek szerinti egyedi beszámolóra való áttérés a pénzügyi intézményeknél. SZAK-ma 59(3), 27-29.

MAJORos PÁL (2011): Tanácsok, tippek, trükkök nem csak szakdolgozatíróknak avagy a kutatásmódszertan alapjai. Budapest: Perfekt.

IBM (2016): The Fisher Exact test for an RxC table is the Fisher-Freeman-Halton Test. http://www-o1. ibm.com/support/docview.wss?uid=swg21479647 (letöltve: 2018.10 .12 .).

Huzsvai László - Vincze Szilvia (2012): SPSS-könyv. Seneca Books (h. n.), http://seneca-books. hu/doc/spsskonyv.pdf (letöltve: 2018.11.01.)

KöкÉNy GÁвоR (2017): IFRS-átállás - Ahogy jelenleg a vállalkozások látják. SZAK-ma 59(3), 25-26.

LIPTÁK VIRÁg (2018): Az IFRS-ek szerinti társasági adózás. SZAK-ma 6o(9), 13-15.

MÉszÁros LÁszLó (2015): A kormány döntött az IFRS-ek egyedi beszámolási célokra történő alkalmazásáról. SZAK-ma 57(6), 276-278.

MNB (2017): V. Aranykönyv. https://www.mnb.hu/felugyelet/idosorok/v-aranykonyv (letöltve: 2018.10.12.).

RAKó ÁGNES (2018): Szemléletváltást igényel az IFRS-ekre történő áttérés. Interjú Rakó Ágnessel. SZAK-ma 60(9), 8-9.

SPSSABC (2018a): Egymintás T-próba. https://spssabc.hu/ketvaltozos-elemzes/egymintas-t-proba/ (letöltve: 2018.10.18.).

SPSSABC (2018b): Fisher teszt. https://spssabc.hu/ketvaltozos-elemzes/fisher-egzakt-teszt/, (letöltve: 2018.10 .12 .

SPSSABC (2018c): Khí-négyzet próba jelentése és alkalmazása az SPSS-ben. https://spssabc.hu/ ketvaltozos-elemzes/khi-negyzet-proba/ (letöltve: 2018.11.01.).

VAJAY JUlianNA (2015): A számvitel nemzetközi harmonizációja az 1970-es évektől napjainkig. Gazdaság és Társadalom 7. évf. Különszám, 88-98, https://doi.org/10.21637/GT.2015.00.07.

VEIT AdRIEnN (2018): Hab az IFRS tortán - Változások az MNB felé történő kötelező adatszolgáltatásban. http://blog.kpmg.hu/2018/o1/hab-az-ifrs-tortan-valtozasok-az-mnb-fele-tortenokotelezo-adatszolgaltatasban/ (letöltve: 2018.11.16.).

Veszprémi István - Molnár GÁbor - Helybély Judit - Jenei Mónika - Ádám Endre (2018): Összefoglaló jelentés a 2018. évi IFRS felmérés eredményeiröl. https://www2.deloitte.com/hu/ hu/pages/audit/articles/ifrs-felmeres.html (letöltve: 2018.11.20.). 